\title{
Prevalence and distribution of serum neutralizing antibodies to San Miguel sea lion virus types 6 and 7 in selected populations of marine mammals
}

\author{
J. E. Barlough*, E. S. Berry**, D. E. Skilling, A. W. Smith \\ Calicivirus Research Laboratory, College of Veterinary Medicine, Oregon State University, Corvallis, Oregon $97331-4802$. \\ USA
}

\begin{abstract}
Neutralizing antibodies to San Miguel sea lion virus (SMSV) types 6 and/or 7 were found in sera collected from California sea lions Zalophus c. californianus in 1977 and 1983, and in sera collected from Steller sea lions Eumetopias jubatus in 1976 and 1985. The combined prevalence rates of SMSV antibodies in these 2 species were: SMSV $-6,19 / 228=8.3 \%$, and SMSV $-7,4 / 228=1.7 \%$. Titers ranged from $1: 20$ to $1: 320$ by standard microtiter neutralization assay. Seropositive sea lions were dispersed along the eastern Pacific rim from Alaska to the southern California Channel Islands. Antibodies to either agent were not found in sera collected from northern fur seals Callorhinus ursinus, Pacific walruses Odobenus rosmarus divergens, seals of the family Phocidae, or several cetacean species. Both SMSV-6 and SMSV-7 have been isolated from opaleye Girella nigricans, an ocean fish found primarily in the southern California coastal zone; the presence of antibody-positive sea lions in more northern waters indicates that these piscine-origin SMSV types may have a wider distribution in nature than has been previously supposed.
\end{abstract}

\section{INTRODUCTION}

The nutrient-laden waters of the north Pacific Ocean and Bering Sea are home to a rich array of vertebrate and invertebrate life forms; so too are they the habitat of a unique family of pathogenic RNA viruses, the Caliciviridae. Evidence indicates that caliciviruses are actively circulating among a variety of Pacific rim marine species, including pinnipeds, cetaceans, and fish (Smith \& Akers 1976, Smith 1981, Barlough et al. 1986, Smith et al. 1986). These viruses are of considerable importance because they are morphologically and physicochemically indistinguishable from the exotic disease agent, vesicular exanthema of swine virus (VESV), and are capable of producing vesicular disease in experimentally exposed pigs (Bachrach \& Hess 1973. Schaffer \& Soergel 1973, Smith et al. 1973, 1977, 1980b,

\footnotetext{
- Present address: Department of Veterinary Microbiology, Immunology and Parasitology, New York State College of Veterinary Medicine, Comell University, Ithaca, New York 14853, USA

- Present address: Department of Veterinary Science, North Dakota State University, Fargo, North Dakota 58105, USA
}

Breese \& Dardiri 1977, Wilder et al. 1977, Wilder \& Dardiri 1978). Such findings have served to support the hypothesis that the costly outbreaks of vesicular exanthema of swine (VES) that spread throughout California and eventually to the remainder of the United States between 1932 and 1956 originated from calicivirus reservoirs in the sea. The feeding of viruscontaminated fish scraps and marine mammal remains to domestic swine has been proposed as the major means by which these 'marine caliciviruses' gained access to terrestrial populations (Madin 1973, Smith \& Akers 1976, Sawyer et al. 1978, Smith et al. 1980b, Smith 1981, Barlough et al. 1986).

In 1976 a previously unrecognized calicivirus serotype, San Miguel sea lion virus type 7 (SMSV-7), was recovered on 2 occasions from opaleye fish Girella nigricans inhabiting tidal pools on San Nicolas Island, a member of the southern California Channel Islands group (Smith et al. 1980b). Subsequent inoculation of this virus into domestic swine resulted in clinical VES, with both primary and secondary vesicular lesions, and horizontal transmission to contact control pigs. SMSV-7 was isolated also from several northern elephant seals 
Mirounga angustirostris resident on San Nicolas Island, and from a trematode (sea lion liver fluke, Zalophatrema spp.) removed from the biliary tract of a California sea Iion Zalophus c. californianus. In 1977 another calicivirus, SMSV-6, previously isolated from pinnipeds, was also recovered from opaleye on San Nicolas (Smith et al. 1979, 1980b). The habitat of the opaleye lies almost entirely within the breeding range of a natural predator, the California sea lion; thus it has been proposed that these fish may act as reservoirs for marine caliciviruses, passing infections on to pinnipeds and to secondary mammalian hosts, such as swine or other domestic species (Smith et al. 1980a, b, Smith 1981).

In this paper we report the results of a seroepizootiologicai investıgation of Pacific Ocean and Bering Sea marine mammals for serum neutralizing (SN) antibodies to piscine calicivirus isolates SMSV-6 and SMSV-7. The purpose of this study was to delineate the geographical distribution of these 2 southern California calicivirus isolates in order to determine whether they are restricted to opaleye-inhabited waters or whether their range (like that of several other calicivirus serotypes) might extend farther northward, where calicivirus transmission cycles remain poorly characterized.

\section{MATERIALS AND METHODS}

Plaque-purified SMSV-6 and SMSV-7 were propagated in Vero (African green monkey kidney) cells as described previously (Smith et al. 1980b). Virus was harvested by freeze-thawing culture flasks, followed by low-speed centrifugation of culture fluids for removal of cell debris. Supernatants were dispensed in $0.2 \mathrm{ml}$ aliquots into screw-cap glass vials and stored at $-70^{\circ} \mathrm{C}$. Stock aliquots of SMSV-6 and SMSV -7 contained ca $10^{6.6}$ and $10^{5.6} \mathrm{TCID}_{50} / 0.025 \mathrm{ml}$, respectively.

A microtiter (96-well) SN procedure using Vero cells was performed, first to screen sera at a dilution of $1: 20$, and then to titrate positive samples (Monto \& Bryan 1974, Smith et al. 1976). Serum-virus mixtures were incubated for $60 \mathrm{~min}$ at room temperature prior to addition of cells. The antibody titer (as judged by cytopathic effect after $72 \mathrm{~h}$ incubation at $37^{\circ} \mathrm{C}$ ) was defined as the highest dilution of serum completely neutralizing $100 \mathrm{TCID}_{50}$ of stock virus in all 4 replicate test wells $(100 \%$ end-point).

California sea lion sera were obtained from 72 pups, 3 to 4 mo of age, during autumn tagging operations on San Miguel Island, California. Forty-three of these sera were collected in 1977, and 29 in 1984. Ten additional sera were obtained from injured or stranded sea lions undergoing rehabilitation at the California Marine Mammal Center (CMMC), Fort Cronkhite, California, in 1983 .

Five Steller sea lion Eumetopias jubatus sera were obtained in the eastern Bering Sea during the spring 1976 cruise of the NOAA research vessel 'Surveyor'. One serum was provided by the CMMC in 1983. Additional sera were obtained from 71 adults, 3 subadults, and 29 fetuses removed from pregnant females, during sampling operations in the vicinity of Kodiak Island, Alaska, in the spring of 1985 . Thirty-seven sera were obtained from $E$. jubatus pups $\leq 6$ wk of age, during tagging operations on Rogue Reef, near the mouth of the Rogue River, Gold Beach, Oregon, in June 1985.

Northern fur seal Callorhinus ursinus sera were obtained from 13 pups, 3 to 4 mo of age, on San Miguel Island in September 1976 . Forty sera from subadult/ adult fur seals were collected on St Paul Island (Pribilof group), Alaska, in 1978. Sera from 2 individuals were provided by the CMMC in 1983. Thirteen additional pup sera and 1 adult serum were collected on San Miguel in September 1984.

Pacific walrus Odobenus rosmarus divergens sera were collected from 68 individuals in the western Bering Sea, during a 1984 joint Soviet-American research cruise aboard the F/V 'Zakharovo'.

Northern elephant seal sera were obtained from 10 individuals at the CMMC in 1983. An additional 56 sera were collected from adults and subadults during feeding studies carried out on San Miguel Island in April 1985.

Hawaiian monk seal Monachus schauinslandi sera were obtained in 1985 from 4 adults and 1 pup, during relocation procedures on islands of the Hawaiian Leeward chain.

One ringed seal Phoca hispida serum sample was obtained in Alaskan waters in 1975. Sera from 10 spotted seals Phoca largha, 4 ribbon seals Histriophoca fasciata, 2 Pacific harbor seals Phoca vitulina richardsi, and 1 bearded seal Erignathus barbatus were obtained in the eastern Bering Sea in 1976. Thirty harbor seal sera were collected at Grays Harbor, Washington, in $1979 ; 17$ additional harbor seal sera were obtained in 1983 from the CMMC.

Killer whale Orcinus orca sera were collected in May 1985 from 3 captive adults at Sealand of the Pacific, Victoria, British Columbia, Canada.

Sera from 16 captive Atlantic bottlenosed dolphins Tursiops truncatus and 3 captive Pacific bottlenosed dolphins Tursiops gillii maintained in San Diego, California, were collected in 1979.

Blood cells were removed from samples by lowspeed centrifugation. The sera were then heat-inactivated $\left(57^{\circ} \mathrm{C}\right.$ for $\left.30 \mathrm{~min}\right)$ in preparation for SN testing. All samples were stored at $-20^{\circ} \mathrm{C}$. 


\section{RESULTS AND DISCUSSION}

The prevalence and distribution of SN antibodies to SMSV-6 and SMSV-7 in the marine mammal populations under study are presented in Table 1. Neutralizing antibodies were found only in the 2 sea lion species sampled (Zalophus c. californianus and Eumetopias jubatus), with higher prevalence rates in E. jubatus $(10.3 \%$ for SMSV-6 and $2.7 \%$ for SMSV-7). Animals seropositive for SMSV-6 showed a wide geographical and temporal distribution, ranging from the coast of Alaska $(1976,1985)$, to Oregon (1985), to California
(1977, 1983). The distribution of animals seropositive for SMSV-7 was more restricted, being limited to Steller sea lions sampled in Oregon and Alaska in 1985.

End-point titration results for the seropositive animals are shown in Table 2. Eleven of the 23 positive samples were of high titer $(\geq 1: 80$ ). One animal, an adult female Steller sea lion sampled near Kodiak Island, Alaska, had a neutralizing antibody titer of 1:320 to SMSV-7.

The overall prevalence of SMSV- 6 antibodies in the entire marine mammal serum collection was 19/523= $3.6 \%$; among pinnipeds of the family Otaridae, 19/365

Table 1. Results of serologic testing for SN antibodies to SMSV-6 and SMSV-7 in populations of marine mammals

\begin{tabular}{|c|c|c|c|c|c|}
\hline \multirow[t]{3}{*}{ Taxa } & \multirow{3}{*}{$\begin{array}{l}\text { Location and year of } \\
\text { sample collection }\end{array}$} & \multicolumn{4}{|c|}{ Serologic results } \\
\hline & & \multicolumn{2}{|c|}{ No. positive/no. sampled } & \multicolumn{2}{|c|}{$\%$ positive } \\
\hline & & SMSV-6 & SMSV-7 & SMSV-6 & SMSV -7 \\
\hline \multicolumn{6}{|l|}{ Otariid pinnipeds } \\
\hline \multirow[t]{4}{*}{ California sea lion } & San Miguel Island, California $(1977)^{\mathrm{a}}$ & $3 / 43$ & $0 / 43$ & $?$ & 0 \\
\hline & Fort Cronkhite, California (1983) & $1 / 10$ & $0 / 10$ & 10 & 0 \\
\hline & San Miguel Island, California $(1984)^{a}$ & $0 / 29$ & $0 / 29$ & 0 & 0 \\
\hline & Total & $4 / 82$ & $0 / 82$ & 4.9 & 0 \\
\hline \multirow[t]{6}{*}{ Steller sea lion } & Eastern Bering Sea (1976) & $1 / 5$ & $0 / 5$ & 20 & 0 \\
\hline & Fort Cronkhite, California (1983) & $0 / 1$ & $0 / 1$ & 0 & 0 \\
\hline & Near Kodiak Island Alaska (1985) & $5 / 74$ & $2 / 74$ & 6.7 & 2.7 \\
\hline & Near Kodiak Island, Alaska $(1985)^{\mathrm{b}}$ & $0 / 29$ & $1 / 29$ & 0 & 3.4 \\
\hline & Rogue Reef, Oregon $(1985)^{\mathrm{a}}$ & $9 / 37$ & $1 / 37$ & 24.3 & 2.7 \\
\hline & Total & $15 / 146$ & $4 / 146$ & 10.3 & 2.7 \\
\hline \multirow[t]{6}{*}{ Northern fur seal } & San Miguel Island, California $(1976)^{a}$ & $0 / 13$ & $0 / 13$ & 0 & 0 \\
\hline & St. Paul Island, Alaska (1978) & $0 / 40$ & $0 / 40$ & 0 & 0 \\
\hline & Fort Cronkhite, California (1983) & $0 / 2$ & $0 / 2$ & 0 & 0 \\
\hline & San Miguel Island, California (1984) & $0 / 1$ & $0 / 1$ & 0 & 0 \\
\hline & San Miguel Island, California $(1984)^{a}$ & $0 / 13$ & $0 / 13$ & 0 & 0 \\
\hline & Total & $0 / 69$ & $0 / 69$ & 0 & 0 \\
\hline Pacific walrus & Western Bering Sea (1984) & $0 / 68$ & $0 / 68$ & 0 & 0 \\
\hline \multicolumn{6}{|l|}{ Phocid pinnipeds } \\
\hline \multirow[t]{3}{*}{ Northern elephant seal } & Fort Cronkhite, California (1983) & $0 / 10$ & $0 / 10$ & 0 & 0 \\
\hline & San Miguel Island, California (1985) & $0 / 56$ & $0 / 56$ & 0 & 0 \\
\hline & Total & $0 / 66$ & $0 / 66$ & 0 & 0 \\
\hline \multirow[t]{3}{*}{ Hawaiian monk seal } & Hawaiian Leeward Islands (1985) & $0 / 4$ & $0 / 4$ & 0 & 0 \\
\hline & Hawaiian Leeward Islands $(1985)^{a}$ & $0 / 1$ & $0 / 1$ & 0 & 0 \\
\hline & Total & $0 / 5$ & $0 / 5$ & 0 & 0 \\
\hline Ringed seal & Barrow, Alaska (1975) & $0 / 1$ & $0 / 1$ & 0 & 0 \\
\hline Spotted seal & Eastern Bering Sea (1976) & $0 / 10$ & $0 / 10$ & 0 & 0 \\
\hline Ribbon seal & Eastern Bering Sea (1976) & $0 / 4$ & $0 / 4$ & 0 & 0 \\
\hline \multirow[t]{4}{*}{ Pacific harbor seal } & Eastern Bering Sea (1976) & $0 / 2$ & $0 / 2$ & 0 & 0 \\
\hline & Grays Harbor, Washington (1979) & $0 / 30$ & $0 / 30$ & 0 & 0 \\
\hline & Fort Cronkhite, California (1983) & $0 / 17$ & $0 / 17$ & 0 & 0 \\
\hline & Total & $0 / 49$ & $0 / 49$ & 0 & 0 \\
\hline Bearded seal & Eastern Bering Sea (1976) & $0 / 1$ & $0 / 1$ & 0 & 0 \\
\hline \multicolumn{6}{|l|}{ Cetaceans } \\
\hline Killer whale & Victoria, British Columbia (1985) & $0 / 3$ & $0 / 3$ & 0 & 0 \\
\hline Atlantic bottlenosed dolphin & San Diego, California (1979) & $0 / 16$ & $0 / 16$ & 0 & 0 \\
\hline Pacific bottlenosed dolphin & San Diego, California (1979) & $0 / 3$ & $0 / 3$ & 0 & 0 \\
\hline \multicolumn{6}{|l|}{ a Pups } \\
\hline${ }^{\mathrm{b}}$ Fetuses & & & & & \\
\hline
\end{tabular}


Table 2. Neutralizing antibody titers to SMSV-6 and SMSV -7 in seropositive marine mammals

\begin{tabular}{|lcrr|}
\hline Species & SN titer & \multicolumn{2}{c|}{ No. of sera } \\
& & & \\
& & 78 & 82 \\
California & $<1: 20$ & 1 & 0 \\
sea lion & $1: 20$ & 2 & 0 \\
& $1: 40$ & 1 & 0 \\
& $1: 80$ & $4 / 82$ & $0 / 82$ \\
& No. positive/ & & \\
Steller sea & no. examined & 131 & 142 \\
lion & $1: 20$ & 6 & 1 \\
& $1: 20$ & 1 & 1 \\
& $1: 40$ & 5 & 1 \\
& 1.80 & 3 & 0 \\
& $1: 160$ & 0 & 1 \\
& No. positive/ & $15 / 146$ & $4 / 146$ \\
& no. examined & & \\
\hline
\end{tabular}

$=5.2 \%$; and among sea lion species (subfamily Otariinae), $19 / 228=8.3 \%$. The overall prevalence of SMSV -7 antibodies in this collection was $4 / 523=$ $0.8 \%$; among pinnipeds of the Otariidae, $4 / 365=$ $1.1 \%$; and among sea lion species, $4 / 228=1.7 \%$. Northern fur seals, Pacific walruses, phocid seals and cetaceans were uniformly negative for SN antibodies to either SMSV serotype.

Data collected over the past $15 \mathrm{yr}$ indicate that the California and Steller sea lions are more intimately involved in marine calicivirus transmission cycles than any other mammalian species thus far examined. Collectively, 8 of the 12 recognized serotypes of SMSV have been recovered at least once from these animals, and seroepizootiologic surveys have demonstrated widespread exposure to these and other marine calicivirus types, including the VESV's (for general reviews see Barlough et al. 1986 and Smith et al. 1986). A major enzootic focus of this activity exists in the southern California coastal zone, where opaleye and California sea lions are believed to be the primary participants in an enzootic/epizootic cycle of calicivirus transmission (Smith et al. 1980a, b).

Opaleye (also known as button perch, blue-eyed perch, or Catalina perch) are members of the Girellinae subfamily of sea chubs (Baxter 1966, Feder et al. 1974, McClane 1978). They can be found over rocky bottoms and around kelp beds in shallow California coastal waters, where they provide considerable sport for fishing enthusiasts. Their range extends generally southward from Monterey Bay to Baja California, with the greatest abundance south of Point Conception; occasional specimens may be recovered as far north as Oregon (Bond \& Olson 1985). Thus their habitat lies almost entirely within the breeding range of one of their natural predators, the California sea lion. Opaleye are omnivorous scavengers that acquire initial calicivirus infections prubably by ingestion of contaminated fecal material. Because these fish also are recognized intermediate hosts for the sea lion lungworm Parafilaroides decorus (Dailey 1970), the suggestion has been made that lungworm larvae excreted in feces may facilitate calicivirus transmission by ferrying viruses, either biologically or mechanically, between sea lions and opaleye (Hardy, quoted in Smith et al. 1980a). Once inside the fish, the parasites encyst in the gut wall where they reside in a form infective for pinnipeds. Opaleye are known to live for as long as 10 yr or more, and encysted lungworm larvae may remain viable for a significant portion of this time (Baxter 1966. Smith et al. 1980a). Theoretically, then, a single opaleye might, over time, accumulate its own unique collection of encysted parasites, some infected possibly with one or more calicivirus serotypes, and thus serve as a swimming calicivirus 'repository', awaiting ingestion by a sea lion or other pinniped. Experimental studies support the feasibility of such a nematode-fish-marine mammal transmission cycle (Smith et al. 1980a, 1981). Taken together, these data have engendered speculation that opaleye, and perhaps other sea lion prey species, may serve as reservoir hosts for marine caliciviruses, passing infections on to pinnipeds and to secondary mammalian hosts (swine or other domestic species).

The seroepizootiologic data reported in the current study extend these earlier findings. Evidence has been presented for the presence of both SMSV-6- and SMSV-7-infected sea lions in far northern (Alaskan) waters, well beyond the range of either opaleye or the California sea lion; the possibility thus exists that the Steller sea lion could represent a transmission link between the southern and northern zones. The Steller sea lion is the largest and most abundant sea lion species in the world, with a wide distribution along the northern Pacific rim from Japan to southern California, overlapping considerably with that of the California sea lion along the western coast of the lower continental United States (Kenyon \& Rice 1961, Fiscus \& Baines 1966, Jameson \& Kenyon 1977. Braham et al. 1980, Schusterman 1981, King 1983). In southern Oregon, considerable intermixing of the 2 sea lion species occurs at certain times of the year in the lower reaches of the Rogue River and on Rogue Reef, several km northwest of the river mouth (Jameson \& Kenyon 1977). This commingling, which frequently occurs in shallow embayments at the perimeter of the reef and at haulout sites, provides a possible mechanism for contact transmission of caliciviruses from one sea lion species to another. Male California sea lions on their northward post-breeding migration might carry caliciviruses with 
them from southern California coastal waters and thus serve as a source of infection for the Steller population. The extremely rare finding of opaleye as far north as Oregon during El Niño years suggests that more direct transmission (feeding on infected fish) could also occur. In addition, Steller sea lions are occasionally found as far south as the Santa Barbara Channel Islands, where they could acquire infections and transport the viruses northward. There are northward and southward migrations of Steller sea lions involving the Alaskan groups and the more southern population; however, little information is currently available regarding the details and extent of these movements (Schusterman 1981). Thus the importance of the Steller species in possible transport of caliciviruses from one region to another remains speculative.

The confinement of SMSV-6 and SMSV -7 antibodies to sea lion species was by no means an unexpected finding. The vast majority of caliciviruses isolated to date from marine mammals have been obtained from members of the subfamily Otariinae (for reviews see Barlough et al. 1986 and Smith et al. 1986). Virologic and serologic studies indicate that California and Steller sea lions figure prominently in calicivirus transmission cycles. Phocid seals (only distantly related to otariids) for the most part are infected only rarely, although recoveries of SMSV-7 from pups of one of these species (northern elephant seal) have been made (Smith et al. 1980b). Such interspecies variation in calicivirus infection patterns (which has been observed for many years) is believed to reflect dissimilar feeding habits and differences in prey selection; thus if certain near-shore sea lion prey species are indeed essential reservoirs for marine caliciviruses, then the seemingly extensive involvement of sea lions in the spread and transmission of caliciviruses may have a relatively straightforward explanation.

Acknowledgements. This work was supported by Veterinary Medicine Research, College of Veterinary Medicine, and the Oregon Agricultural Experiment Station, Oregon State University, Project No. 785. The authors gratefully acknowledge the generous assistance of the following individuals in the collection of serum samples: George A. Antonelis, Jr, Henry Bray, Robin Brown, Tom Cox, Dr Robert L. DeLong, Dr Leslie Dierauf, Blane Ebbert, William G. Gilmartin, Enid Goodwin, James Harvey, Sandy Hawes, Steve Jeffries, Jack Lentfer, Mark Lowry, Dr James McBain, Richard L. Merrick, Larry M. Shults, and Brent Stewart. The authors also thank Dr Robert L. Delong of the National Marine Mammal Laboratory, Seattle, Washington, for reviewing an earlier draft of the manuscript.

\section{LITERA.TURE CITED}

Bachrach, H. L., Hess, W. R. (1973). Animal picornaviruses with a single major species of capsid protein. Biochem. biophys. Res. Commun. 55: 141-149
Barlough, J. E., Berry, E. S., Skilling, D. E., Smith, A. W. (1986). The marine calicivirus story, parts I and II. Compend. cont. Ed pract. Vet. 8: F5-F14, 8: F75-F83

Baxter, J. L. (1966). Inshore fishes of California, Revision 3. California Department of Fish and Game, Sacramento, p. $51-52$

Bond, C. E., Olson, R. E. (1985). Northward occurrence of the opaleye Girella nigricans, and the sharpnose seaperch, Phanerodon atripes. Calif. Fish. Game 71. 56-57

Braham, H. W., Everitt, R. D., Rugh, D. J. (1980). Northern sea lion population decline in the eastern Aleutian Islands. J. Wildl. Mgmt 44: 25-33

Breese, S. S., Dardiri, A. H. (1977), Electron microscope observations on a virus transmissible from pinnipeds to swine. J. gen. Virol. 36: 221-225

Dailey, M. D. (1970). The transmission of Parafilaroides decorus (Nematoda: Metastrongyloidea) in the California sea lion (Zalophus californianus). Proc. helminth. Soc. Wash. 37: 215-222

Feder, H. M., Turner, C. H., Limbaugh, C. (1974). Observations on fishes associated with kelp beds in southern California. Calif. Fish Game Fish. Bull. 160: 46-47

Fiscus, C. H., Baines, G. A. (1966). Food and feeding behavior of Steller and California sea lions. J. Mammal. 47. 195-200

Jameson, R. J., Kenyon, K. W (1977). Prey of sea lions in the Rogue River, Oregon. J Mammal. 58: 672

Kenyon, K. W., Rice, D. W. (1961). Abundance and distribution of the Steller sea lion. J. Mammal. 42: 223-234

King, J. E. (1983). Seals of the world, 2nd edn. Cornell University Press, Ithaca

McClane, A. J. (1978). McClane's field guide to saltwater fishes of North America. Holt, Rinehart and Winston, New York

Madin, S. H. (1973). Pigs, sea lions, and vesicular exanthema. Proc. 2nd Int. Conf. Foot and Mouth Dis. Gustav Stern Foundation, New York, p. 78-81

Monto, A. S., Bryan, E. R. (1974). Microneutralization test for detection of rhinovirus antibodies. Proc. Soc exp. Biol. Med. 145: 690-694

Sawyer, J. C., Madin, S. H., Skilling, D. E. (1978). Isolation of San Miguel sea lion virus from samples of an animal food product produced from northern fur seal (Callorhinus ursinus) carcasses. Am. J. vet. Res. 39: 137-139

Schaffer, F. L., Soergel, M. E. (1973). Biochemical and biophysical characterization of calicivirus isolates from pinnipeds. Intervirology 1: 210-219

Schusterman, R. J. (1981). Steller sea lion - Eumetopias jubatus. In: Ridgway, S. H., Harrison, R. J. (eds.) Handbook of marine mammals, Vol. 1. Academic Press, New York, p. 119-141

Smith, A. W. (1981). Marine reservoirs for caliciviruses. In Steele, J. H. (ed.) CRC handbook series in zoonoses, Sect B, Vol. II. CRC Press, Boca Raton, p. 182-190

Smith, A. W., Akers, T. G. (1976). Vesicular exanthema of swine. J. Am. vet.-med. Ass. 169: 700-703

Smith, A. W., Akers, T. G., Latham, A. B, Skilling, D. E., Bray, H. L. (1979). A new calicivirus isolated from a marine mammal. Arch. Virol. 61: 255-259

Smith, A. W., Akers, T G., Madin, S. H., Vedros, N. A. (1973). San Miguel sea lion virus isolation, preliminary characterization and relationship to vesicular exanthema of swine virus. Nature, Lond, 244: 108-110

Smith, A. W., Akers, T G., Prato, C. M., Bray, H. (1976). Prevalence and distribution of four serotypes of SMSV serum neutralizing antibodies in wild animal populations. J. Wildl. Dis. 12: 326-334

Smith, A. W., Prato, C. M., Skilling, D. E. (1977). Characteriza- 
tion of two new serotypes of San Miguel sea lion virus. Intervirology $8: 30-36$

Smith, A. W., Skilling, D. E., Barlough, J. E, Berry, E. S (1986). Distribution in the North Pacific Ocean, Bering Sea, and Arctic Ocean of animal populations known to carry pathogenic caliciviruses. Dis. aquat. Org. 2: 73-80

Smith, A. W., Skilling, D. E., Brown, R. J. (1980a). Preliminary investigation of a possible lung worm (Parafilaroides decorus), fish (Girella nigricans), and marine mammal (Callorhinus ursinus) cycle for San Miguel sea lion virus type 5. Am. J. vet. Res. 41. 1846-1850

Smith, A. W., Skilling, D. E., Dardiri, A. H., Latham, A. B. (1980b). Calicivirus pathogenic for swine: a new serotype isolated from opaleye Girella nigricans, an ocean fish. Science 209: 940-941

Smith, A. W. Skilling, D. E., Prato, C. M., Bray, H. L. (1981). Calicivirus (SMSV-5) infection in experimentally inoculated opaleye fish (Girella nigricans). Arch. Virol. 67. 165-168

Wilder, F. W., Dardiri, A. H. (1978). San Miguel sea lion sius fed to mink and pigs. Can. J. comp. Med. 42: 200-204

Wilder, F. W. Dardiri, A. H., YedJoutschnig, R. J., Ugstad, P. O. (1977). Challenge of equines with San Miquel sea lion viruses. Proc. U.S. Anim. Health Ass. 81. 270-275

Responsible Subject Editor: Dr M. D. Dailey; accepted for printing on July 30, 1988 